\title{
THE CORRELATION BETWEEN DEMOGRAPHIC DEVELOPMENT AND LAND-USE CHANGES IN SLOVENIA
}

Uroš Horvat, Igor Žiberna

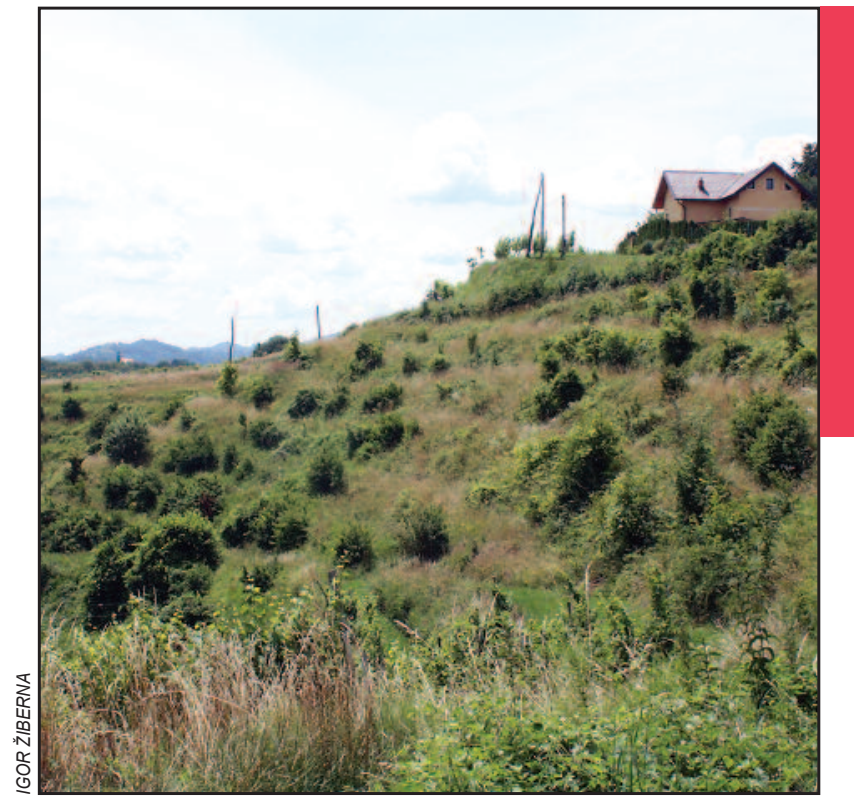

Overgrowth on former terraced vineyards between Dravinjski Vrh and Majski Vrh in eastern Haloze region (northeastern Slovenia). 
DOI: https://doi.org/10.3986/AGS.7611

UDK: 911.3:711.14:314(497.4)

COBISS: 1.01

\section{Uroš Horvat $^{1}$, Igor Žiberna ${ }^{1}$}

\section{The correlation between demographic development and land-use changes in Slovenia}

ABSTRACT: The paper focuses on determining the degree of correlation between land-use changes and demographic development in Slovenia. The authors conclude that there is still insufficient evidence in the literature for a correlation between these two processes, because quantitative studies addressing these links are very rare and mostly cover small and specific areas. In the case of Slovenia, Spearman's correlation coefficients are quite low, which confirms that land-use change processes are complex and not dependent solely on individual demographic and socioeconomic factors. Despite the low correlation coefficients, our findings indicate that changes in land use are significantly influenced by changes in age structure and population growth. In areas with population growth the share of arable land is shrinking, whereas in areas with depopulation and a rising aging index the share of partially overgrown land is growing. In the following analysis, the authors focus their analysis on a case study of the Mura and Central Slovenia statistical regions, which lie on opposite poles with regard to development, and thus show differing trends in land-use changes.

KEY WORDS: land use, arable land, afforestation, demography, age structure, Slovenia

\section{Povezanost med demografskim razvojem in spremembami rabe zemljišč v Sloveniji}

POVZETEK: Avtorja se osredotočata na ugotavljanje stopnje povezanosti sprememb v rabi zemljišč in demografskim razvojem v Sloveniji. Ugotavljata, da v literaturi ni dovolj dokazov o povezavi med obema procesoma, saj so kvantitativne študije, ki obravnavajo te povezave, zelo redke in večinoma vezane na proučevanje prostorsko majhnih in specifičnih območij. Tudi na primeru Slovenije so Spearmanovi koeficienti korelacije precej nizki, kar potrjuje da so procesi spreminjanja rabe zemljišč kompleksni in niso odvisni le od posameznih demografskih in socio-ekonomskih dejavnikov. Kljub nizkim korelacijskim koeficientom pa rezultati nakazujejo, da na procese spreminjanja rabe zemljišč pomembno vplivajo spremembe $\mathrm{v}$ starostni sestavi prebivalstva in rast prebivalstva. $\mathrm{V}$ območjih $\mathrm{z}$ rastjo prebivalstva se obseg obdelovanih površin zmanjšuje, $v$ območjih depopulacije in višanja indeksa staranja pa narašča delež zemljišč v zaraščanju. V nadaljevanju analize se avtorja osredotočita na analizo primera v Pomurski in Osrednjeslovenski statistični regiji, ki glede na stopnjo razvitosti ležita na nasprotnih polih, in kažeta različne trende $\mathrm{v}$ spremembah rabe zemljišč.

KLJUČNE BESEDE: raba zemljǐ̌č, obdelovalne površine, ogozdovanje, demografija, starostna sestava, Slovenija

This paper was submitted for publication on September 17th, 2019

Uredništvo je prejelo prispevek 17. septembra 2019

\footnotetext{
${ }^{1}$ University of Maribor, Faculty of Arts, Department of Geography, Maribor, Slovenia uros.horvat@um.si, igor.ziberna@um.si
} 


\section{Introduction}

Land use is an element that most distinctly characterizes a specific landscape. It refers to land exploitation through human activity and is a good indicator of landscape structures and processes (Kladnik 1999). It reflects the mutual effects between natural, historical, and socioeconomic factors (Gabrovec and Kladnik 1997). Land use and its changes also reflect changing social values, as well as the impact of various decisions on the transformation of farm production and land use in the past (Bičík, Gabrovec and Kupková 2019). From the very beginning, one of the most important land-use functions has been land cultivation and food production, which ensures the survival of individuals and the human race as a whole.

Harmony between life satisfaction, health, lifelong learning opportunities, feeling of safety, and an appropriate environment is required to ensure appropriate prosperity within a given society (Vrabič and Kek 2012; Tiran 2017). Providing high-quality and healthy food in adequate quantities is an important quality-of-life indicator. One of the most important causes of food shortages is also land-use changes, especially shrinking areas of arable land either due to construction, grass overgrowth, or afforestation (Gabrovec and Kladnik 1997; Gabrovec and Kumer 2019). These processes reduce food security in underdeveloped countries, but in altered economic conditions they may also threaten developed countries (Cuff and Goudie 2009).

Compared to other EU countries, land-use changes in Slovenia show unfavorable self-sufficiency trends. EU land-use data are collected by Eurostat, which in 2009 began issuing annual statistical reports as part of the LUCAS project (Internet 1). The first report covered only twenty-three EU member states, leaving out Bulgaria, Romania, Cyprus, and Malta (Gallego, Palmieri and Ramos 2015). This method differs slightly from the one the Slovenian Ministry of Agriculture uses for its regular online reports on agricultural land use, with the Slovenian method being significantly more detailed (Interpretacijski ključ... 2013), but it nonetheless provides sufficiently good insight into the current state of land use in the EU.

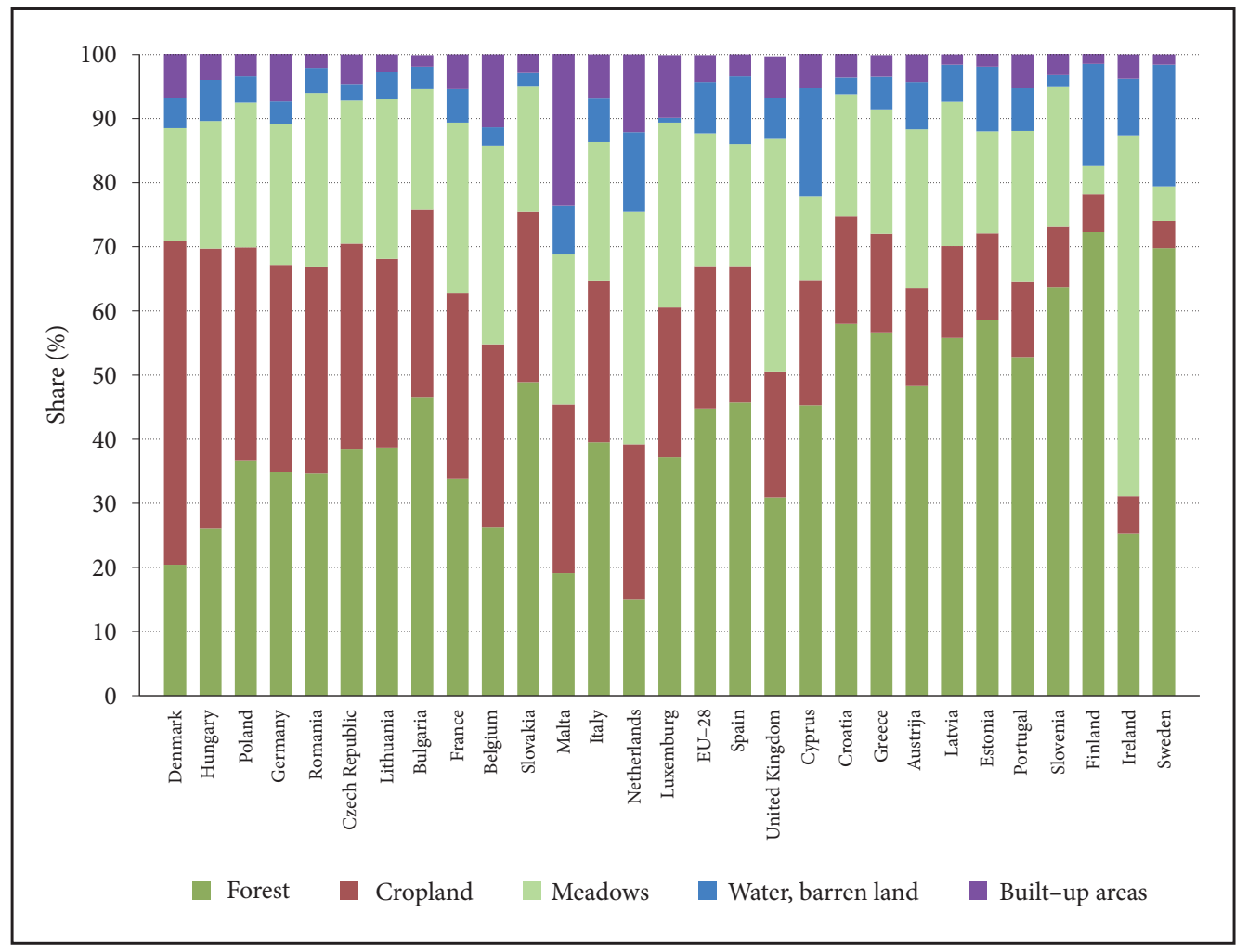

Figure 1: Breakdown of land use in the EU-28 in 2015 (\% of total area). 
According to the 2015 Eurostat data, woodland predominated among the land-use types in the EU-28 (44.9\%), followed by cropland (22.2\%), grassland (20.7\%), water areas and wetlands (8\%), and built-up and other anthropogenically modified land (4.2\%; Figure 1). Scandinavia had the largest share of woodland and Slovenia was in third place (63.7\% wooded). As a rule, the share of cropland (Figure 2) is inversely proportional to the share of woodland. Less than $6 \%$ of cropland was typical of Sweden, Ireland, and Finland, followed by Slovenia (9.5\%). Denmark and Hungary had by far the highest shares ( $50.6 \%$ and $43.7 \%$, respectively). The average share of cropland in the EU-28 was $22.2 \%$.

Compared to other EU member states, Slovenia has an above-average share of woodland and a belowaverage share of cropland. A high share of woodland can be an advantage because forests function as carbon sinks and, in terms of energy industry and economics, wood is an important renewable resource and a raw material whose added value should be increased by the wood industry. However, the high share of woodland in Slovenia also results in a decrease in cropland. According to Plut (2012), a wood cover of approximately $50 \%$ would suffice for a stable balance between food production, ecosystem, and wood in Slovenia.

The area of cropland per capita is an even better self-sufficiency indicator (Figure 3). It is estimated that in the EU climate zone, c. 0.3 hectares of cropland per capita would be required to ensure food independence (Perpar and Kovačič 2006). Conditions in the EU member states are not favorable in this respect.

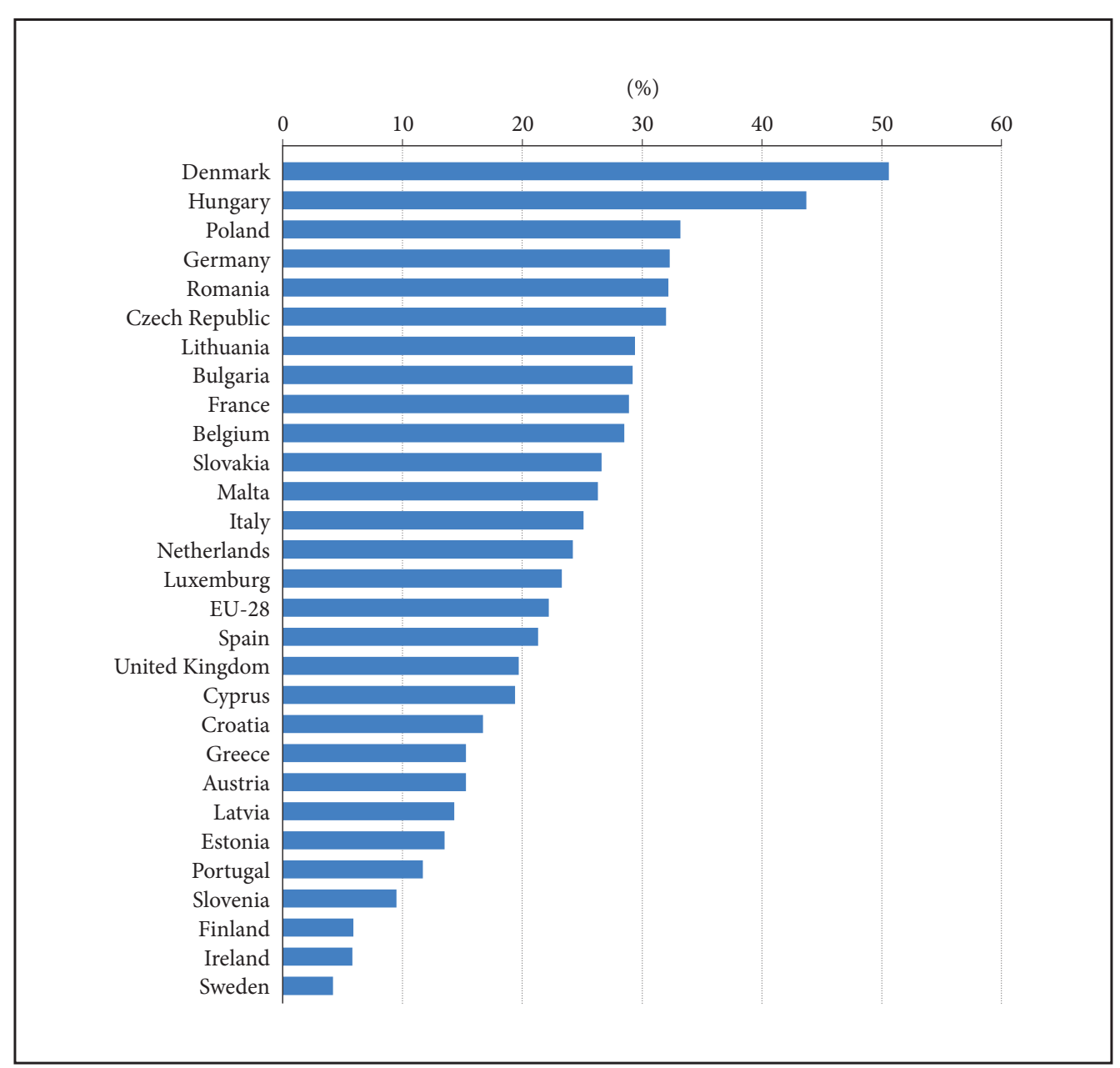

Figure 2: Breakdown of cropland in the EU-28 in 2015 (\% of total area). 
Only twelve countries fulfilled this condition in 2015. Compared to other countries, Slovenia is practically in last place, having only 0.0355 hectares per capita (the EU average being 0.1903 hectares). The problem of food security is thus shared by most EU countries, in which the situation in Slovenia is one of the worst. Monitoring the changes in Slovenia's cropland and maintaining a minimum that still guarantees food security are key factors of future development. It is alarming that in Slovenia cropland is shrinking in the areas with the highest production potential (Žiberna 2018).

Land use and its changes have been relatively well covered in literature. Focusing on Slovenia alone, land-use changes have been examined by many authors, such as Gabrovec and Kladnik (1997), Petek (2002), Petek and Urbanc (2004), Paušič and Čarni (2012), Lisec, Pišek and Drobne (2013), Ribeiro, Ellis Burnet and Torkar (2013), Gabrovec and Kumer (2018), Žiberna (2018), and Ribeiro and Šmid Hribar (2019).

At the same time, the impact of demographic change on land-use change has been relatively poorly covered in quantitative studies. Studies dealing with these correlations are very rare and mostly cover small and specific areas. Rajan and Shibasaki (2000) examined the correlations between population and economic power on the one hand and land-use changes on the other in Thailand. They highlighted the correlations between rural-urban migration and the decline in arable land resulting from an increase in built areas. Shi et al. (2010) analyzed the impact of population dynamics on land-use changes in the Tarim Basin and

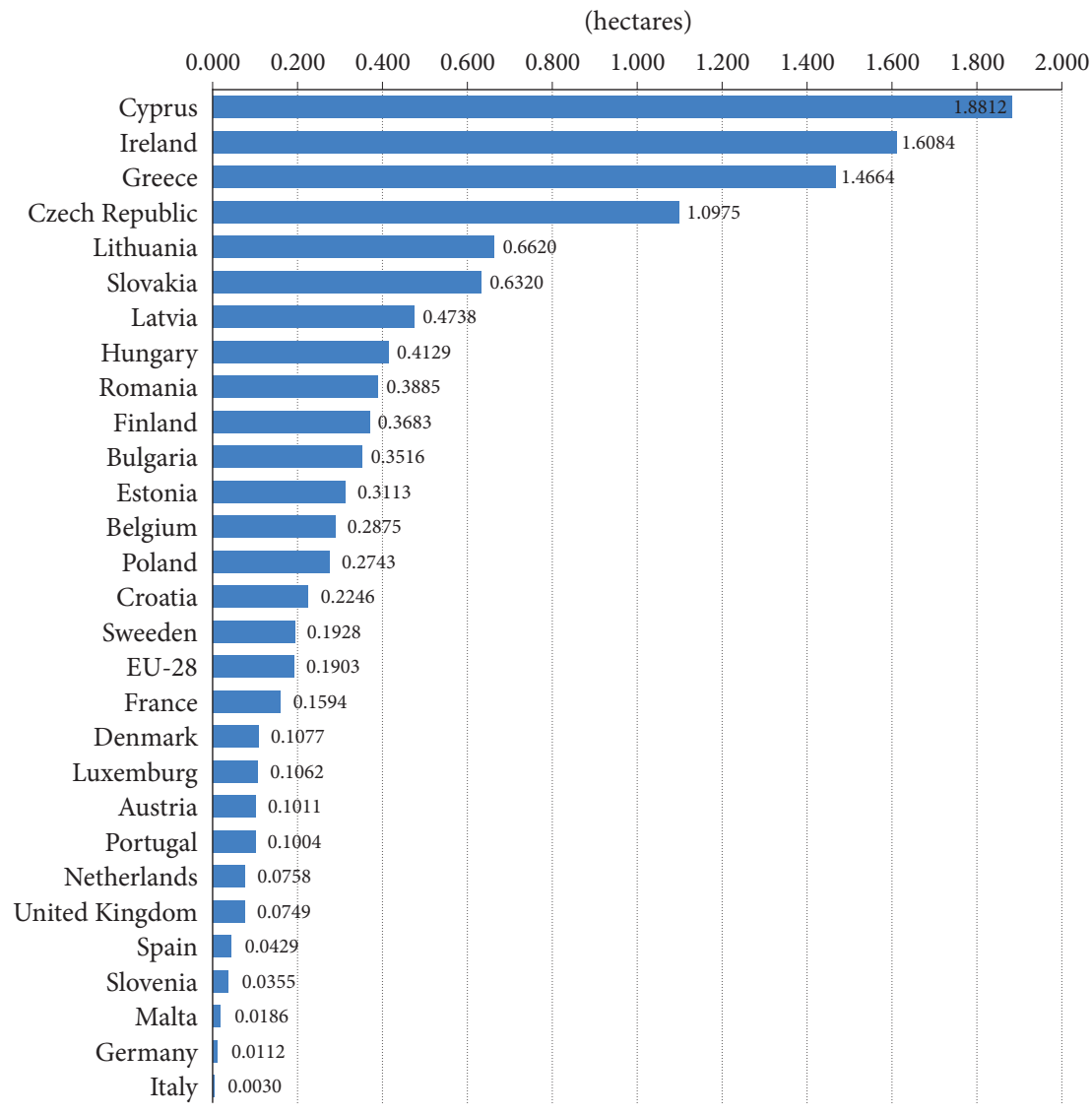

Figure 3: Cropland per capita in the EU-28 in 2015 (in hectares). 
established that population growth drives increases in farmland, primarily to provide the required quantity of food. Gould, Martinuzzi and Parés-Ramos (2012) analyzed the impact of urban population growth on the decrease in arable land in Puerto Rico, whereby they also examined changes in ecosystem services. Hansen et al. (2002) studied the western part of the US to establish that it is not completely clear why the population growth rate, economic conditions, and land-use patterns change faster in some areas than others. Certain areas with similar land use are growing quickly, whereas others in the same region are losing its population. Something similar was also determined by Kroll and Haase (2010), who report that recent demographic change, characterized by a decreasing and aging population, is a main factor influencing future land-use change in Europe. They found a correlation between land use, natural population dynamics, and net migration in most of the growing regions in western Germany, whereas in the eastern German regions with a shrinking population, economic variables are a more important factor influencing land-use change. Their cluster analysis further showed that areas of growth and depopulation in Germany are connected with both urbanization and demographic change, and that neither a decreasing nor an aging population imply reduced land consumption for housing and transportation.

Also relevant to Slovenia is the study by Ferreira and Petek (2005), who defined changes in land use and the socioeconomic structure of the population in northwest Upper Carniola. Their analysis showed that the extensive social changes after the Second World War (i.e., demographic growth, depopulation, abandonment of farming, and intense economic development) caused extensive grass overgrowth and afforestation, which continue today. Ribeiro (2017) also partly examined land use and demographic characteristics at the local level.

This article analyzes the degree of correlation between land-use indicators and selected demographic indicators in Slovenia or, in other words, it uses a quantitative analysis to determine the correlation between land-use change and selected demographic indicators.

\section{Methods}

The 2000 and 2018 land-use data were taken from reports by the Slovenian Ministry of Agriculture, Forestry, and Food, which annually posts land-use data online in .shp format (Internet 2). The vector data for each land-use category was converted into raster data with $5 \times 5 \mathrm{~m}$ cell size. The method for land-use data capture changed between 2000 and 2018, and so the land-use types for 2000 are divided into twenty-one categories and for 2018 into twenty-six. Merging these categories into clusters for analysis yields the following eleven land-use categories: tilled fields and gardens, vineyards, orchards, other perennial plantings, meadows, partially overgrown land, mixed land use, built-up and similar areas, forest, other, and water areas. Following this, land-use structure (in \%) was determined by individual Slovenian municipalities for 2000 and 2018, and the indices of changes in the area of various land-use types between the two years.

After this, the relevant demographic and socioeconomic data were added at the municipal level for 2000 and 2018 (or 2017 if the 2018 data were not yet available at the time of the analysis) from the SiStat SURS database (Internet 3). The focus was on the following indicators: the population change index between 2000 and 2018, average population age, population aging index, old-age dependency ratio, share of population by large age groups, general birth rate, rate of natural increase, net migration rate, and share of population with tertiary education. An additional synthetic indicator was included in the end: the municipal development ratio calculated by the Slovenian Statistical Office (SURS), which also includes certain demographic indicators; the average municipal development ratio is 1.00 (Internet 4).

A table with all the data collected was used as the basis for calculating Spearman's correlation coefficients. The final analysis focused on correlation coefficients with $p<0.0001$.

\section{Demographic development and land-use changes in Slovenia over the past two decades}

Abandonment of farming, industrialization, and urbanization had a key impact on Slovenia's demographic development and settlement network after the Second World War. Klemenčič (1996) reports that three types of areas formed in terms of settlement characteristics and population development: areas of greater pop- 
ulation density with ongoing population growth, depopulation areas with ongoing declines in population, and intermediate areas. Ravbar (1997) adds that like most other European countries during the 1970s Slovenia gradually stepped into a post-industrial industrialization phase characterized by stagnation or decline in the urban population growth, with a simultaneous population growth in the wider peri-urban area.

By 1991, the average annual urban population growth fell to $1.4 \%$, which was lower than the total Slovenian growth rate. To a smaller degree, suburbanization was already present during the 1970s, when it was mainly typical of the settlements closest to Ljubljana; it heavily intensified during the 1980s, and even more during the 1990s. The urban population in Slovenia began to move to increasingly more remote peri-urban settlements, which was related to the spatial transformation of peri-urban areas and urban depopulation (Rebernik 1999; Rebernik 2008).

Suburbanization was influenced by several factors, especially the shortage of appropriate housing in cities, lower land prices in peri-urban settlements, good transport connections between cities and their surroundings, a higher vehicle-ownership rate, development of modern telecommunication devices, more urban pollution, relocation of production and service companies from cities to the surrounding areas, bankruptcy of large industrial businesses, and the consequent higher urban unemployment rates. From 1991 to 2002 , the population of Ljubljana decreased by $3 \%$, of Celje by $7.1 \%$, Kranj by $2.4 \%$, Koper by $4 \%$, and Maribor by $9.7 \%$ (Horvat 2006). The 2009-2018 data show a slightly different situation. The population in Ljubljana has increased (by 4.7\%) due to the growing centralization of all activities in the country. In Maribor, the population has decreased (by 1.8\%), although recently the population has been decreasing more rapidly especially in peripheral medium-sized cities, such as Murska Sobota (4.9\%), Velenje (3.8\%), Slovenj Gradec (3.7\%), and Ptuj (2.9\%; Horvat 2019).

Over the past two decades there have also been certain changes in rural population development. After a long period of decline, after 1991 rural settlements recorded slight growth. According to Ravbar (2007), the rural population decreased by approximately 15\% from 1961 to 1991 and increased by $1.7 \%$ from 1991 to 2002. This trend has continued since then. However, it should be highlighted that demographic growth has only been recorded in rural areas with relatively good access to larger regional centers. Klemenčič (2005) thus distinguishes between two types of rural areas: urbanized and stable rural areas with a high share of non-farming population, and rural areas in risk of dying out or extensive areas of depopulation, rapid shrinking of farmland, and disintegration of cultural landscape. Here, only farmland in the village or close to the village is being cultivated, whereas meadows and pastures outside the villages are partly or fully overgrown with forest.

Data on changes in the population by municipality between 2000 and 2018 (Figure 4) confirm the processes described above. On the one hand, they show areas of greater population density and population growth, which typically occur in suburbanized areas near large cities, and on the other hand areas of depopulation typical mostly of Slovenia's hilly, peripheral, and border areas. Population has only increased in four urban municipalities: Novo Mesto, Ljubljana, Kranj, and Koper. Municipalities in the Central Slovenia Statistical Region stand out with the highest growth indices (120-173), with as many as fourteen municipalities out of the twenty-one in Slovenia where the population has grown by over $20 \%$. Municipalities in the Drava and Upper Carniola statistical regions also stand out in this regard, with each having three municipalities of this type. A population growth of over $30 \%$ has been recorded in the municipalities of Brezovica, Grosuplje, Ig, Komenda, Dol pri Ljubljani, and Škofljica (all part of the Central Slovenia Statistical Region). In turn, the highest depopulation index (75-90) has been recorded in municipalities in the northeast (especially the Mura Valley), west (the Soča Valley), and south and north (along the border with Croatia and Austria). The twenty-five municipalities with the greatest population decrease include nine in the Mura Statistical Region, five in the Gorizia Statistical Region, and four in the Carinthia Statistical Region. In the municipalities of Šalovci, Grad, Cankova, Gornji Petrovci (all in the Mura Statistical Region), Podvelka, and Kanal, the population increased by over $15 \%$.

Slovenia has an older population. Ever since 1961, the share of young people ( $0-14$ years old) has been rapidly decreasing and it nearly halved by 2018 (i.e., it decreased from $27.3 \%$ to $15.0 \%$ ), whereas the share of the elderly (age 65 or more) has been rapidly increasing and it nearly doubled from 2000 to 2018 (i.e., it increased from $7.8 \%$ to $19.4 \%$ ). The average age of the population is also increasing: it rose from 39.5 years in 2002 to 43.2 years in 2018. This is largely the result of longer life expectancy and low birth rates (Slovenia

Figure 4: Population change index by municipality from 2000 to $2018($ Index $(2000)=100) .>$ p. 40 

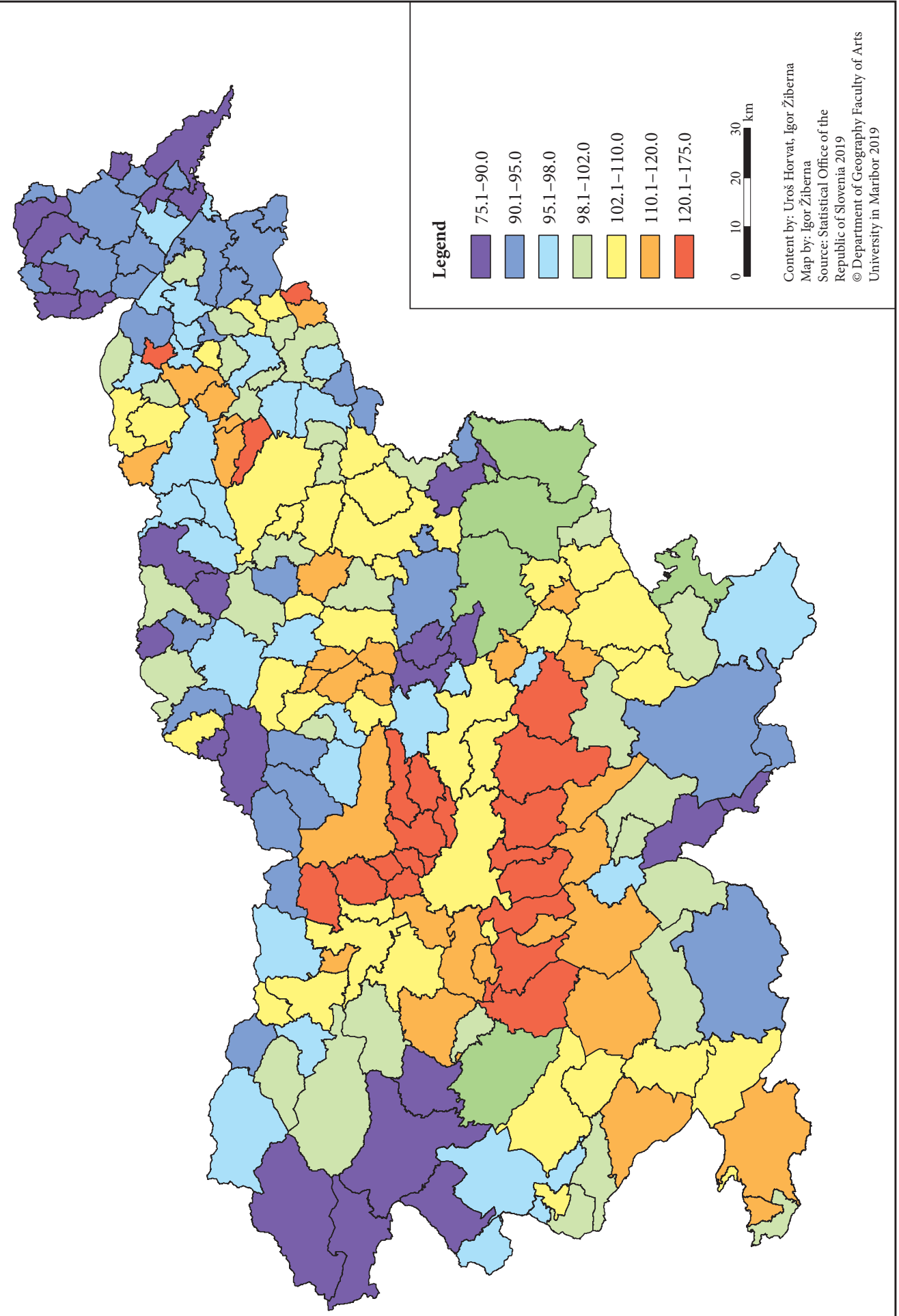
is among the countries with a very low birth rate). The share of younger population is higher in areas with a relatively high birth rate and a positive net migration rate, which are primarily areas of pronounced suburbanization. Population aging has recently also been evident in urban centers: in large cities the share of elderly population has increased significantly, exceeding the values in the surrounding area (Horvat 2019). Pelc (2015) also reported that in 2011 the share of young people was higher in non-urban settlements and the share of the elderly was higher in large cities.

In 2018, among the twenty-three municipalities with an aging index higher than 170 , ten belonged to the Mura Statistical Region and three to the Gorizia Statistical Region (Figure 5). All urban municipalities had an index higher than 100, with the municipalities of Maribor and Murska Sobota recording the highest values (i.e., 178). On the other side of the spectrum there are municipalities with aging indices lower than 95. There are nineteen of these; eleven of them belonged to the Central Slovenia Statistical Region, followed by four in the Southeast Slovenia Statistical Region and three in the Drava Statistical Region.

Slovenia's landscape diversity also causes significant land-use differences. Forests predominate in the Alpine and Dinaric landscapes of western Slovenia, grassland predominates in the hills of eastern Slovenia, intensive farmland is typical of Pannonian lowlands, and built-up areas predominate on the coast and in the Alpine basins (Gabrovec et al. 2020).

In Slovenia, the area covered by arable land (tilled fields, gardens, vineyards, orchards, and other perennial plantings) decreased by 29,847.4 hectares (or 1.5 percentage points) from 2000 to 2018, which amounts to a decrease of 30.21 hectares per week. During the same period, the increase in the area covered by forest was nearly the same (i.e., 27,581.3 hectares or 1.4 percentage points) or 27.92 hectares per week (Table 1). In 2018, the share of arable land was unevenly distributed among municipalities (Figure 6). The highest shares were recorded in lowland municipalities in northeast Slovenia (the Drava, Ptuj, Apače, and Mura basins), of which some even had over $50 \%$ of arable land (between 60 and 70\% in the municipalities of Odranci, Turnišče, Tišina, Beltinci, and Kidričevo). A high share was also typical of municipalities in the Littoral (Izola), Ljubljana Basin (Šenčur, Mengeš, and Komenda), the Gorizia Hills, and the Krško-Brežice Basin (Brežice).

In his analysis of trends in land-use change, Žiberna (2013) reports that from 2000 to 2012 Slovenia acquired 87,614.1 hectares in the process of intensification, but it also lost twice as much (167,610.0 hectares) due to extensification. Only $73.2 \%$ of tilled fields and gardens were preserved during this period. The remaining fourth turned into meadows (45,470.9 hectares or $21.0 \%$ ), built-up and similar areas, partially overgrown land, forests, and other land-use types. According to Žiberna (2018), abandonment of arable land is characterized bybifurcation: high-quality arable land is either turning into built-up areas (this is primarily evident in the suburbs), or into meadows, partially overgrown land or forest (in marginal areas with often unfavorable demographic conditions). Indices of changes in partially overgrown land are the highest in areas with the greatest shares of arable land - that is, northeast Slovenia (Figure 7).

In central and western Slovenia, indices of changes in the size of built-up land (Figure 8) are higher than in northeast Slovenia. The built-up areas around cities spread primarily due to suburbanization (Gabrovec

Table 1: Land-use types in Slovenia by area and percentage, 2000 and 2018.

\begin{tabular}{lcccccc}
\hline Land-use type/Year & $\begin{array}{c}\text { Area (hectares), } \\
2000\end{array}$ & $\begin{array}{c}\text { Area (hectares), } \\
\text { 2018 }\end{array}$ & $\begin{array}{c}\text { Change in area } \\
\text { (hectares), } \\
2000-2018\end{array}$ & $\% 2000$ & $\% 2018 \begin{array}{c}\text { Index, } \\
2000-2018\end{array}$ \\
\hline Tilled fields and gardens & $216,471.9$ & $183,983.0$ & $-32,488.9$ & 10.7 & 9.1 & 85.0 \\
Vineyards & $25,292.7$ & $18,668.2$ & $-6,624.5$ & 1.2 & 0.9 & 73.8 \\
Orchards & $24,891.7$ & $32,518.0$ & $+7,626.3$ & 1.2 & 1.6 & 130.6 \\
Other perennial plantings & $1,182.8$ & $2,822.2$ & $+1,639.4$ & 0.1 & 0.1 & 238.6 \\
Forests & $1,202,285.5$ & $1,229,866.8$ & $+27,581.3$ & 59.3 & 60.7 & 102.3 \\
Meadows & $350,570.1$ & $354,766.5$ & $+4,196.4$ & 17.3 & 17.5 & 101.2 \\
Built-up areas & $108,156.9$ & $112,285.0$ & $+4,128.1$ & 5.3 & 5.5 & 103.8 \\
\hline
\end{tabular}

Figure 5: 2018 population aging index by municipality. $>$ p. 42

Figure 6: Share of arable land by municipality in 2018 (\%). > p. 43

Figure 7: Index of changes in partially overgrown land by municipality, $2000-2018(2000=100)$. p p. 44

Figure 8: Index of changes in built-up areas by municipality, $2000-2018(2000=100)$. $>$ p. 45 

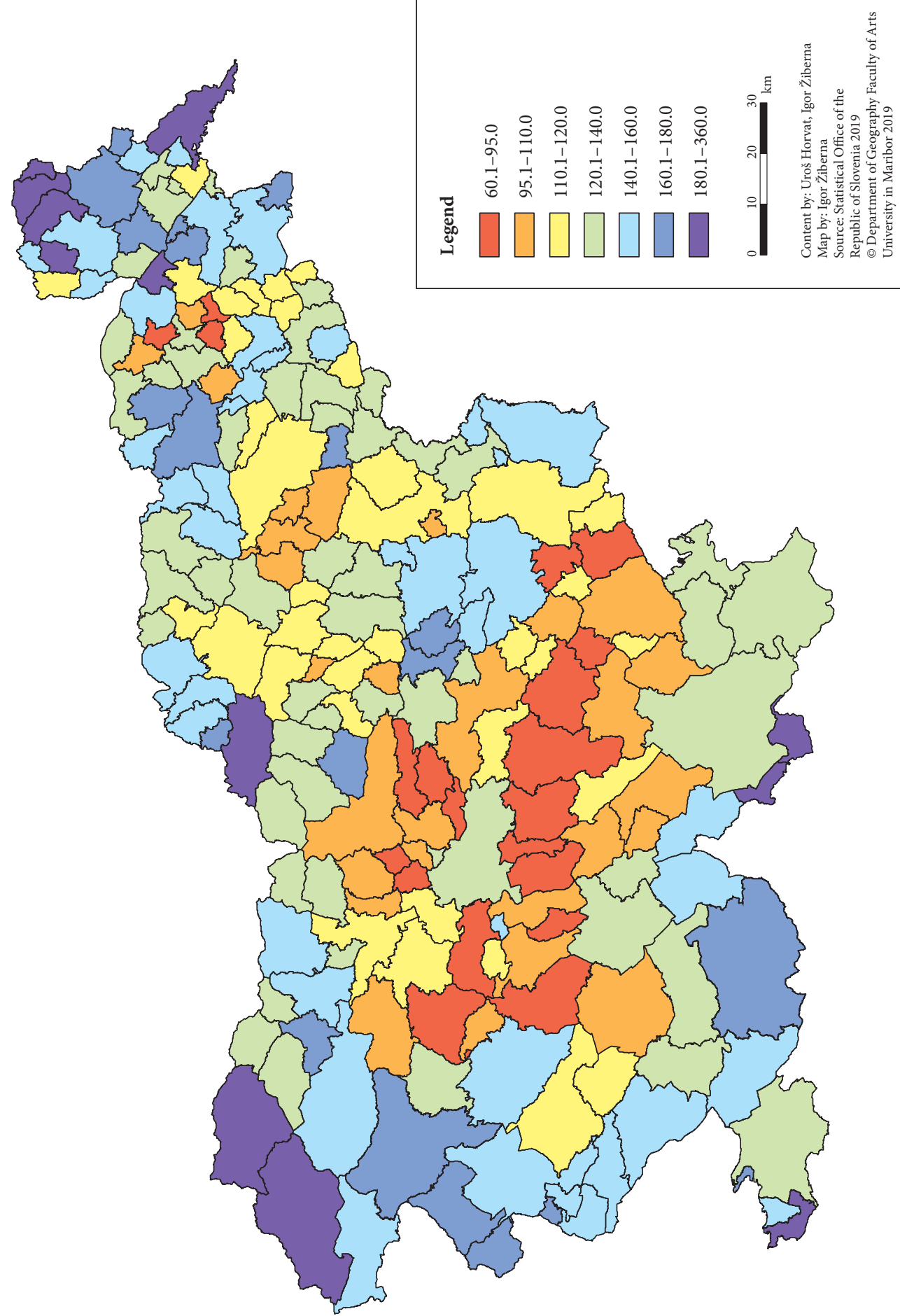


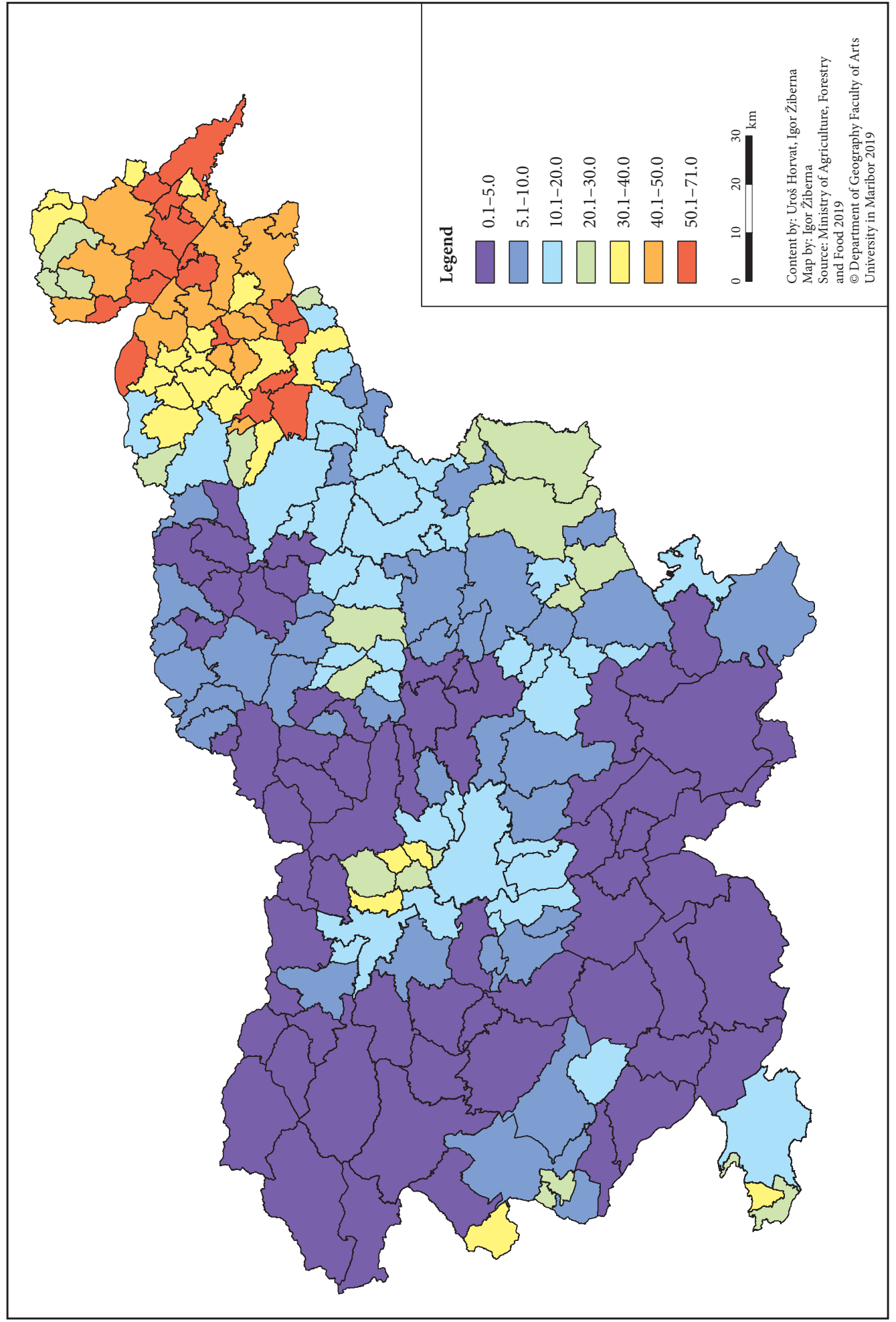



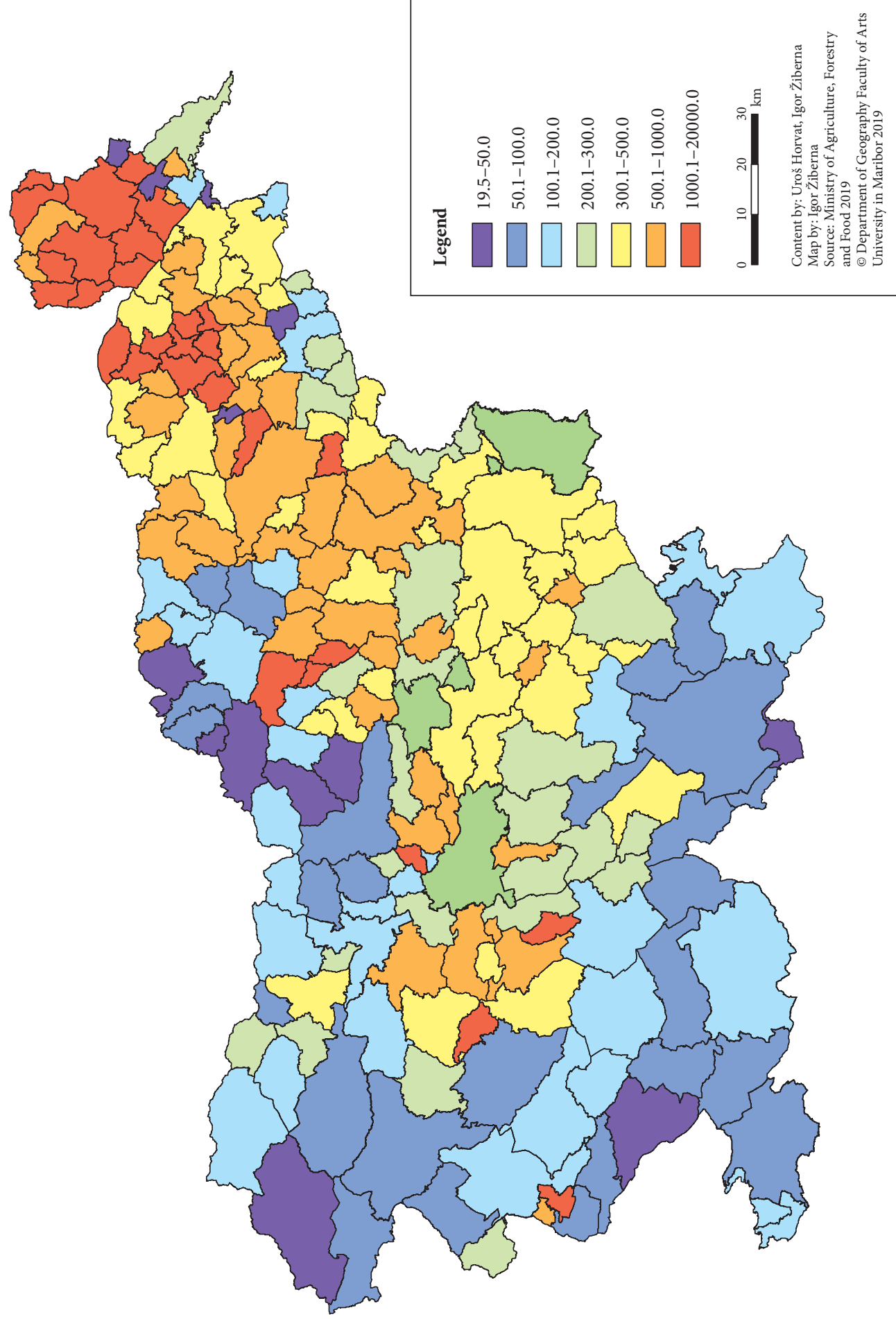


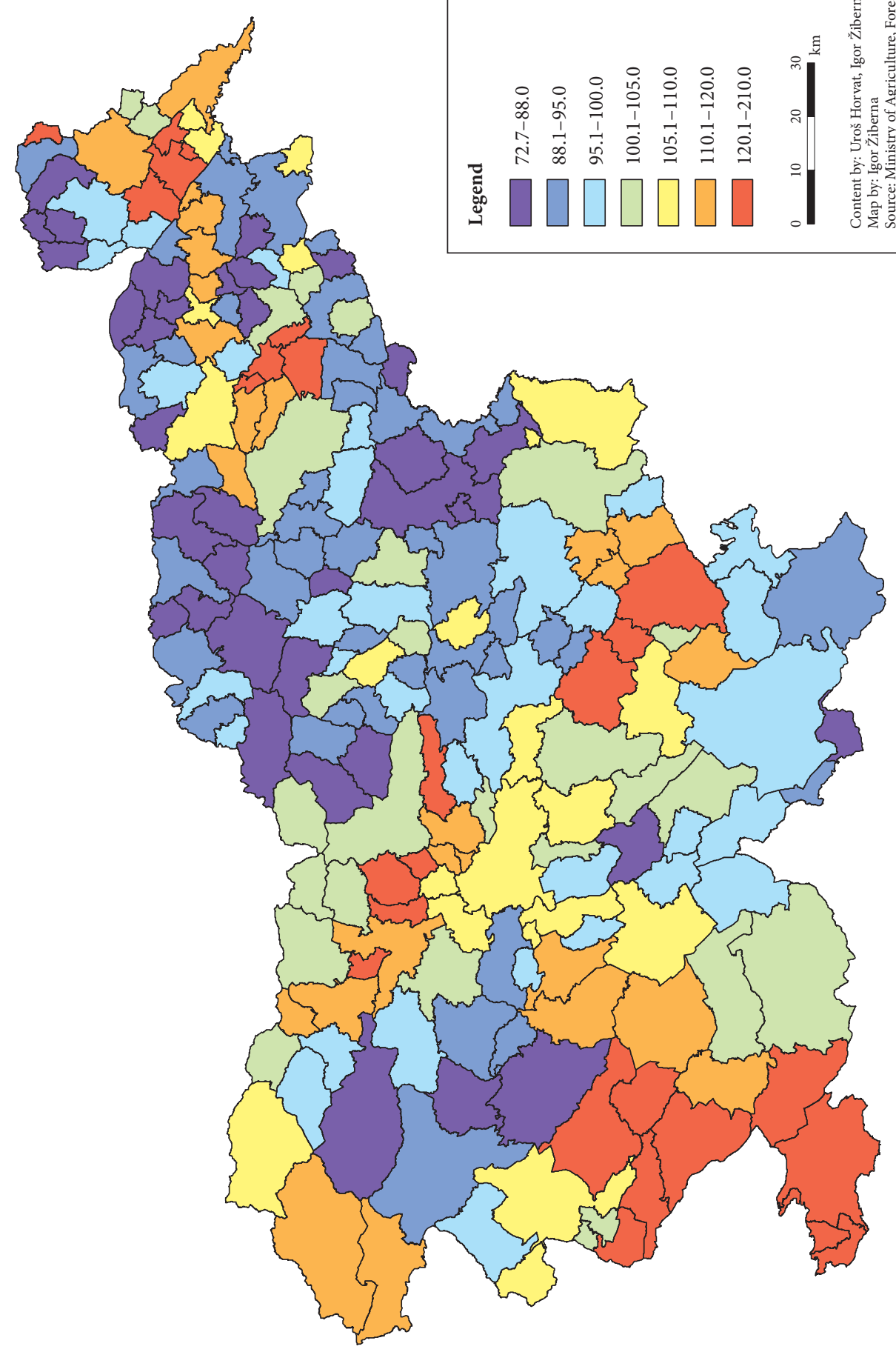


and Kumer 2018). During the period studied, high positive indices were observed in municipalities in the Ljubljana Basin (Komenda: 154.4, Cerklje na Gorenjskem: 152.6, Lukovica: 135.6, and Naklo: 132.1), southwest Slovenia (Piran: 209.7, Ankaran: 152.9, Vipava: 140.4, Hrpelje-Kozina: 137.5, and Sežana: 128.8), and individual municipalities in Lower Carniola (Mirna Peč: 156.8, Novo Mesto: 133.4, and Miren-Kostanjevica: 128.0) and northeast Slovenia (Turnišče: 149.8, Hodoš: 144.8, Starše: 136.1, and Kidričevo: 126.0).

As anticipated, the analysis of Spearman's correlation coefficients for selected indicators by municipality showed high coefficients between various interconnected demographic indicators that define the population's age structure (mostly over \pm 0.80 ). The coefficients of correlation with other demographic indicators are lower and do not exceed \pm 0.80 . Hence, the correlation coefficient between the population change index and the share of young people (younger than fourteen) is 0.63 , and the coefficient between the population change index and the population aging index is -0.61 . The general birth rate and the population aging index have a negative correlation coefficient (i.e., -0.73 ). It is interesting that the share of population with tertiary education does not show a high correlation with most indicators (it is below \pm 0.50 ); the only exceptions are the population change index (0.55) and the municipal development ratio (0.62), which shows a trend of highly educated population moving to areas with high population density.

Spearman's correlations coefficients are also somewhat higher between indicators defining various landuse types and changes. There is an exceptionally high negative correlation between the share of forest and the shares of tilled land $(-0.89)$ land built-up areas $(-0.72)$. Among the indicators demonstrating changes in land use between 2000 and 2018, the highest positive correlations are typical of the index of changes in partially overgrown land, showing that this land is increasing in areas with a higher share of arable land $(0.52)$ and tilled fields $(0.50)$, and the highest negative correlation is in areas with a higher share of forest $(-0.50)$. There is also high correlation between the index of changes in forest and the index of changes in partially overgrown land (0.68), indicating that afforestation is still ongoing.

Spearman's correlation coefficients are significantly lower between the demographic and land-use indicators (Table 2), which confirms the initial premise that the land-use change processes are complex and not dependent solely on individual demographic and socioeconomic factors. The 2018 share of tilled fields and gardens is negatively correlated with the share of people eighty years old or more $(-0.30)$. The share of partially overgrown land has a weak positive correlation with the aging index $(0.25)$ and the average age of the population (0.24), and consequently a negative correlation with the share of people in the $0-14$ age group $(-0.36)$. The share of built-up areas is positively correlated with the changes in the population over the 2000-2018 period (0.33) and negatively correlated with the share of people eighty years old or more $(-0.25)$. Differences in the share of arable land between 2000 and 2018 are negatively correlated with the population change index during the same period $(-0.35)$. The index of changes in arable land is negatively correlated with the share of people in the $0-14$ age group $(-0.26)$. Despite low correlation coefficients, the results indicate that the processes of land-use change largely depend on changes in the age structure of the Slovenian population and changes in the population, considering that in areas where the population is growing the amount of arable land is decreasing (the correlation coefficient between the two is -0.46 ).

\section{Case study: Central Slovenia and Mura statistical regions}

The data above refer to Slovenia as a whole but, as mentioned above, there are significant differences between individual areas due to Slovenia's pronounced geographical diversity. To further elucidate these differences, the focus hereafter is on the analysis at the level of statistical regions, which proved to be sufficiently large territorial units. The analysis is limited to the Mura and Central Slovenia statistical regions, where the bifurcation of land-use change mentioned above is the most pronounced. These two statistical regions are complete opposites in terms of their municipal development ratios (Figure 9) and most demographic indicators.

A comparison between the population change index from 2000 to 2018 and the municipal development ratio in the two statistical regions (Figure 10) shows two typical clusters: during the study period, in nearly all municipalities in the Mura region the population change index was lower than 100 , and the municipal development ratio was also at the lower end. The municipalities of Hodoš (0.4) and Šalovci (0.5) had the lowest municipal development ratios in Slovenia. In the Central Slovenia region, the population change index was above 100 in all municipalities, with the highest ones recorded in the municipalities of Škofljica (172.5), Dol pri Ljubljani (144.3), and Komenda (142.2). All top eleven municipalities with the highest 


\begin{tabular}{|c|c|c|c|c|c|c|c|c|c|c|c|c|c|c|c|}
\hline $\begin{array}{r}(\angle L O Z) \\
\text { o!̣e ұuәudo|әләр |ed!̣!unW }\end{array}$ & & \begin{tabular}{c}
$\infty$ \\
\hdashline \\
1
\end{tabular} & & $\bar{n}$ & $\bar{n}$ & & $\stackrel{\infty}{m}$ & & & ஜn. & & ì & $\underset{\infty}{0}$ & $\stackrel{2}{i}$ & \\
\hline 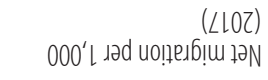 & & & & $\stackrel{\sim}{\sigma}$ & & & & & & & & & & $\stackrel{\infty}{\dddot{0}}$ & 崩 \\
\hline 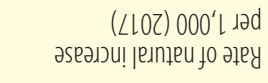 & & & & & ڤ్ & & & & & & & $\bar{n}$ & & & \\
\hline 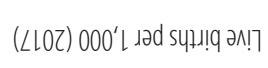 & & & & $\approx$ & & & & & & $\stackrel{2}{2}$ & & ஜ̂. & & & \\
\hline (८LO乙) әъех ұиәшко|dшәип & స్తి & 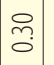 & $\overline{\tilde{o}}$ & & $\approx$ & & & $\stackrel{\infty}{0}$ & $\bar{n}$ & m. & & & & & \\
\hline 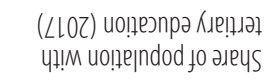 & & $\begin{array}{c}\approx \\
0 \\
1\end{array}$ & $\begin{array}{l}\hat{\sigma} \\
0 \\
1\end{array}$ & & 管 & & ঠి & & & & & & 吕 & ते & \\
\hline 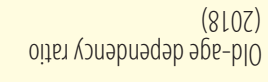 & స్ & $\approx$ & $\hat{\tilde{m}}$ & \begin{tabular}{c}
\multirow{1}{*}{} \\
0 \\
1
\end{tabular} & & $\lesssim$ & & 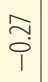 & $\begin{array}{l}2 \\
0 \\
0 \\
1\end{array}$ & & $\stackrel{\substack{0 \\
i}}{1}$ & & & & \\
\hline $\begin{array}{r}(810 z) \\
+08 \text { uo!̣e|ndod f0 วеuS }\end{array}$ & ஜ̂. & & & $\stackrel{0}{\infty}$ & & $\stackrel{\infty}{\sigma}$ & $\stackrel{2}{2}$ & \begin{tabular}{l}
\multirow{2}{*}{} \\
0 \\
1
\end{tabular} & & & స్ & & & & \\
\hline $\begin{array}{r}(810 Z) \\
+\varsigma 9 \text { uo!!e|ndod jo əRuS }\end{array}$ & & & & $\begin{array}{c}\text { f} \\
0 \\
i\end{array}$ & & & & & & & & & & & \\
\hline 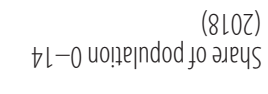 & & $\begin{array}{l}0 \\
0 \\
i \\
1\end{array}$ & & $\tilde{n}$ & ֻৃ. & & & & mi & 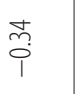 & & $\stackrel{\infty}{i}$ & & ؟ै & \\
\hline (8เ०z) xәри! бu! бy & & & & $\begin{array}{r}q \\
0 \\
0\end{array}$ & $\underset{\sigma}{2}$ & & & & & & & $\tilde{n}$ & & & \\
\hline $\begin{array}{r}(8107-0007) \\
\text { әбиечว әбе әбеләнН }\end{array}$ & & & & & & & & & & & & & & $\stackrel{\infty}{0}$ & \\
\hline (8เо乙) әбе әбецәАн & & & & \begin{tabular}{l}
7 \\
\multirow{1}{*}{} \\
1
\end{tabular} & & & & & & & & $\tilde{\sigma}$ & & సે & \\
\hline $\begin{array}{r}(810 z-000 z) \\
\text { xәри! әбиечว uo!!ep|ndod }\end{array}$ & & & & 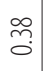 & & & $\ddot{n}$ & & & & & & $\bar{\sigma}$ & $\begin{array}{l}0 \\
0.1 \\
0 \\
0\end{array}$ & $\stackrel{n}{n}$ \\
\hline 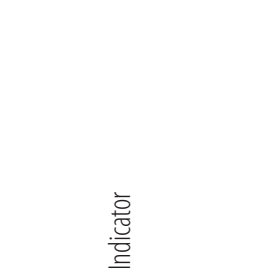 & 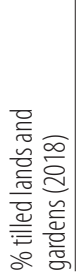 & 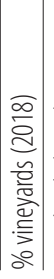 & 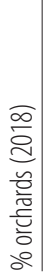 & 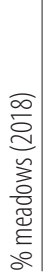 & 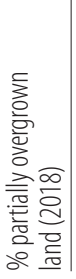 & 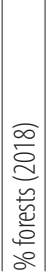 & 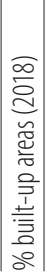 & 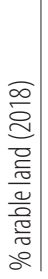 & 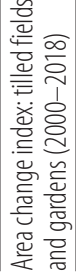 & 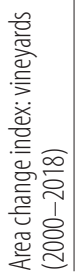 & 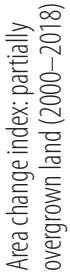 & 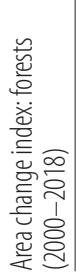 & 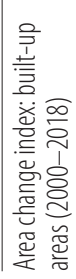 & 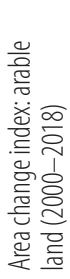 & 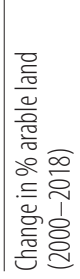 \\
\hline
\end{tabular}




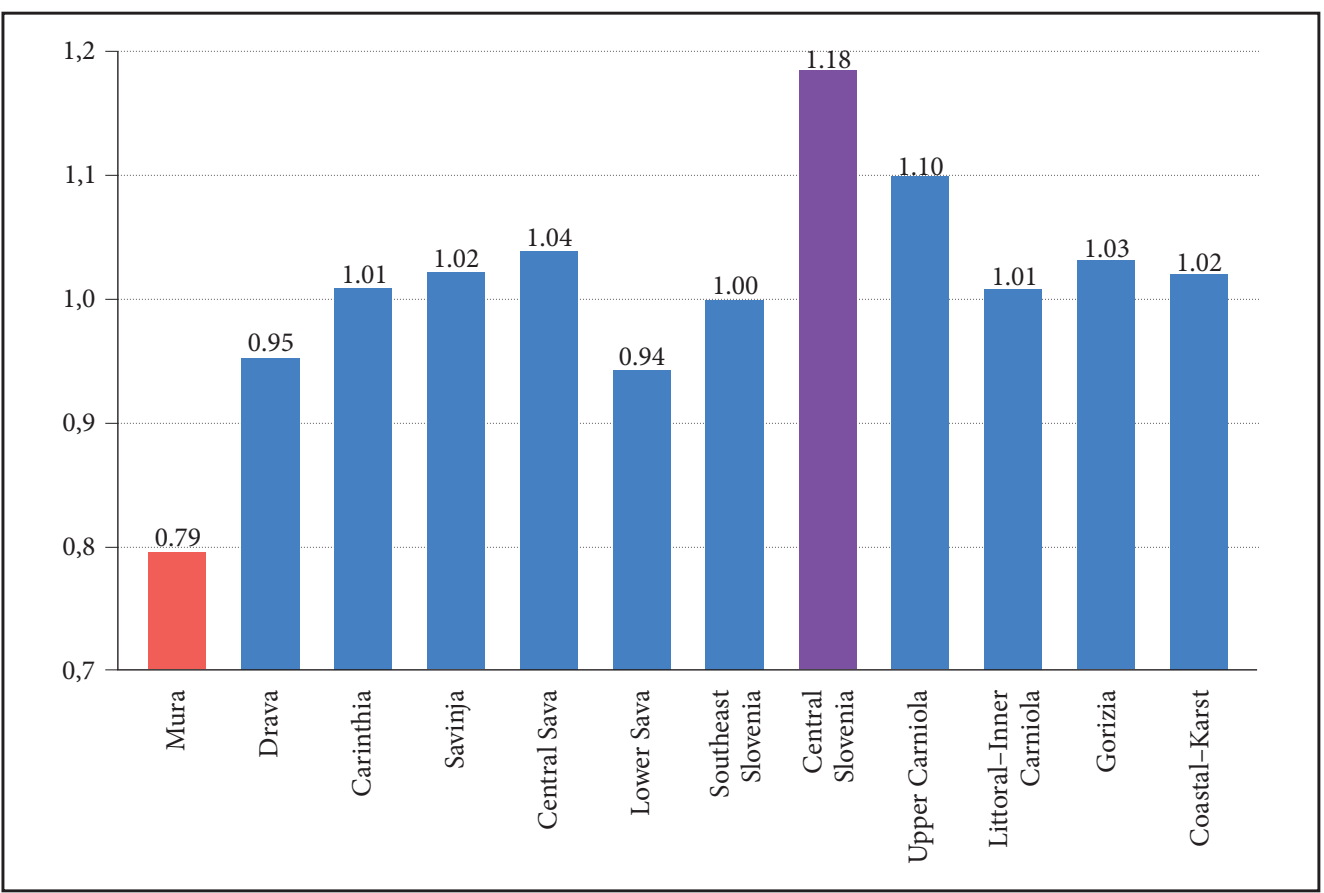

Figure 9: Municipal development coefficient by statistical region in 2018.

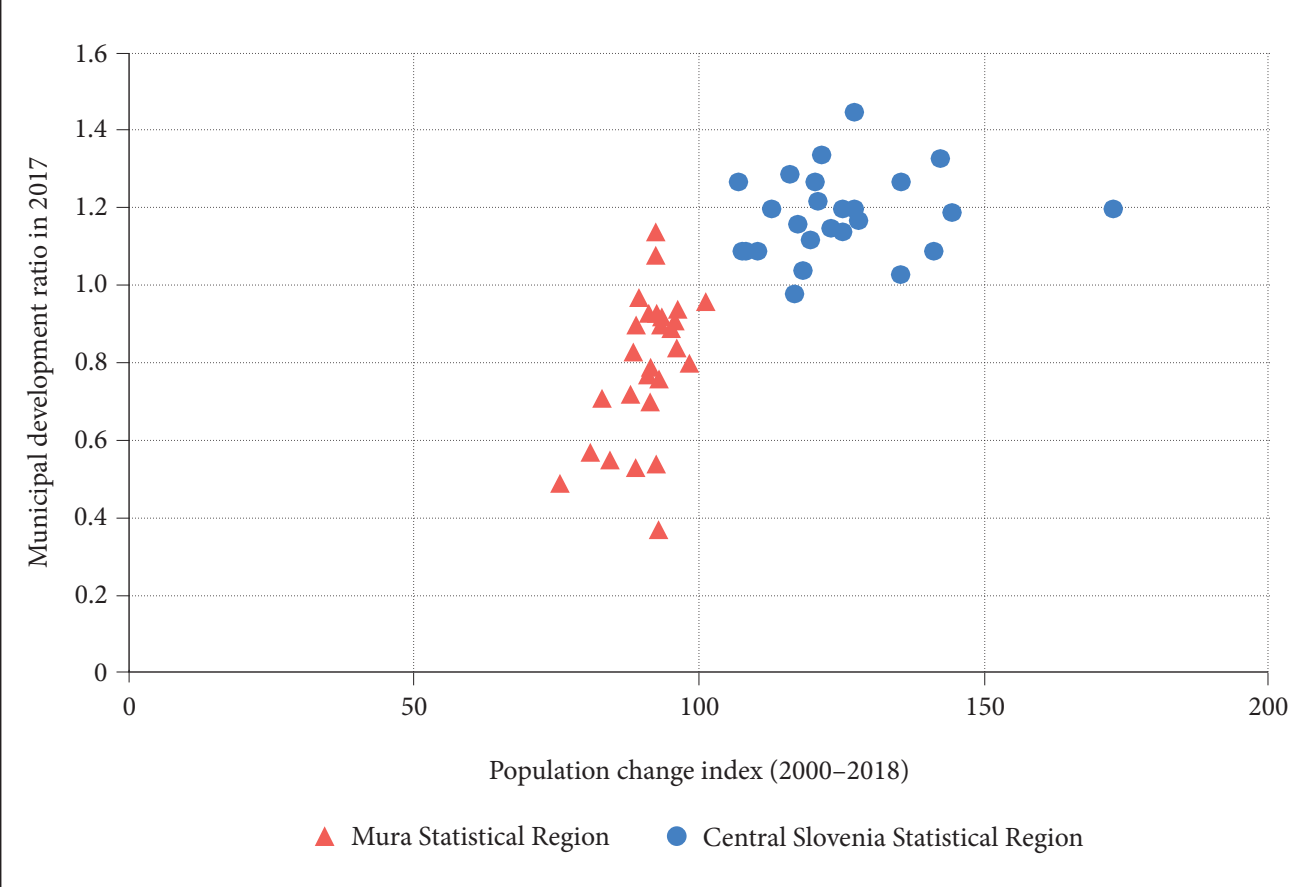

Figure 10: Population change index (2000-2018) and the municipal development ratio in the Mura and Central Slovenia statistical regions. 
population change index can be found in the Central Slovenia region, whereas the municipalities of Šalovci (75.5) and Grad (80.9) can be found at the very bottom (both from the Mura region).

A contrast between the two statistical regions can also be identified by comparing the population change index between 2000 and 2018 and the index of arable land change (Figure 11). In addition to population change indices lower than 100 , the municipalities in the Mura region are characterized by arable land change indices between 90 and 100. In the Central Slovenia region, the population change indices are above 100 and the indices of arable land change are below 90, which shows that, in parallel with suburbanization, population growth in this region causes significant shrinking of arable land.

In the Mura region, the shrinking of arable land due to grass overgrowth is more pronounced than in other parts of Slovenia. Half of the ten municipalities with the highest index of change in partially overgrown land between 2000 and 2018 (Figure 12) can be found in this region, which reconfirms the thesis that unfavorable processes of arable land extensification are present in areas with the highest production potential. In Central Slovenia region this shrinking is significantly less common. Even though the average age of Slovenia's population is increasing, the intensity of this process is not evenly distributed across regions. The share of partially overgrown land increases with the increase in the aging index (Figure 13), in which this correlation is more pronounced in the Mura region. The reasons for arable land being overgrown thus can be sought not only in depopulation, but also pronounced population aging.

Spearman's correlation coefficients for all of Slovenia showed a relatively weak correlation between the selected indicators. Through further analysis, the correlation coefficients were also calculated at the level of selected statistical regions (Tables 3 and 4). Due to smaller scales, less landscape diversity, and lower impacts of various other factors, Spearman's correlation coefficients by statistical region showed significantly higher correlations, which in some cases can even be over \pm 0.80 . The Mura region shows clear positive correlations $(0.30-0.60)$ between indicators revealing population growth, a younger age structure, and a higher share of population with tertiary education, and indicators revealing a higher share of built-up areas. On the other hand, a positive correlation $(0.30-0.60)$ is also shown between indicators revealing population aging and depopulation, and indicators revealing a higher share of partially overgrown land and forest.

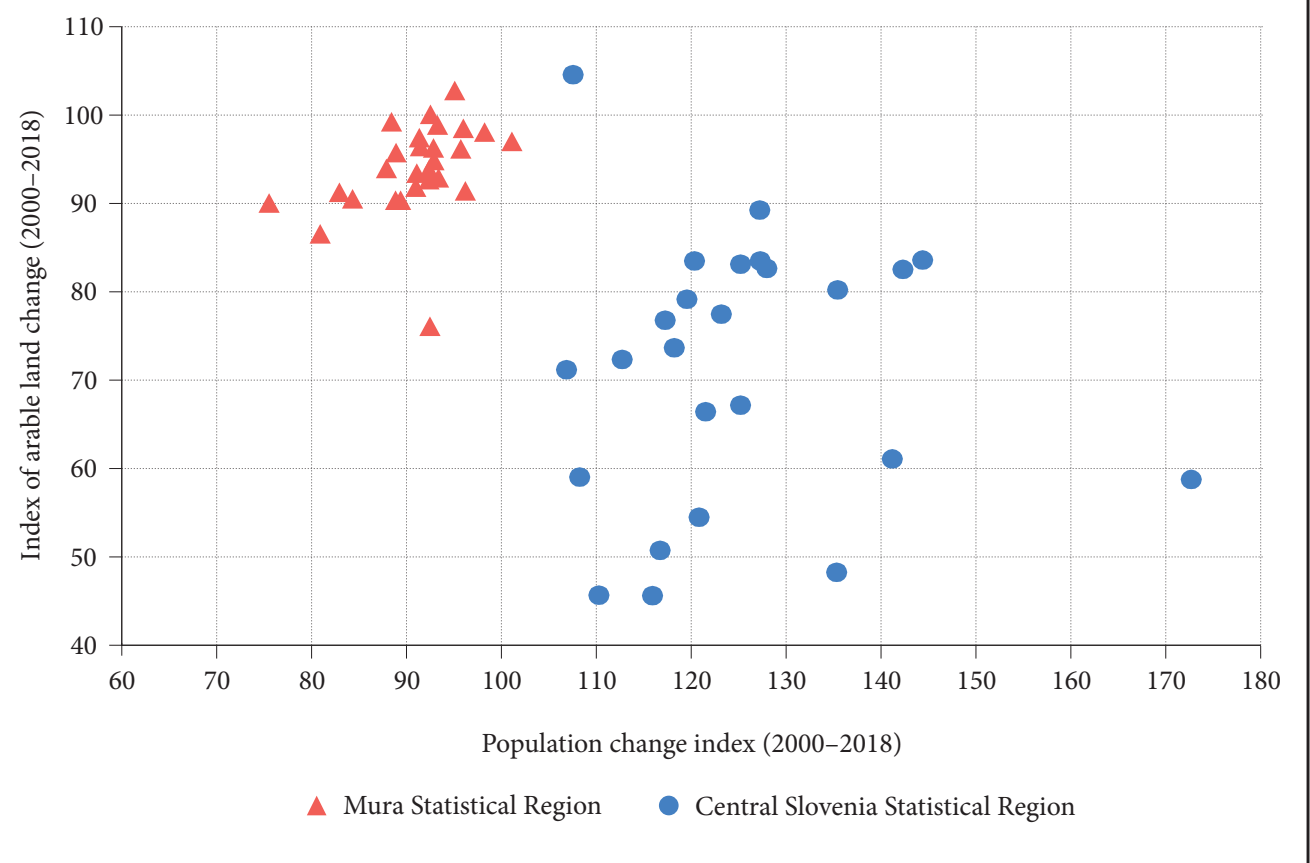

Figure 11: Population change index and index of arable land change in municipalities of the Mura and Central Slovenia statistical regions, 2000-2018. 


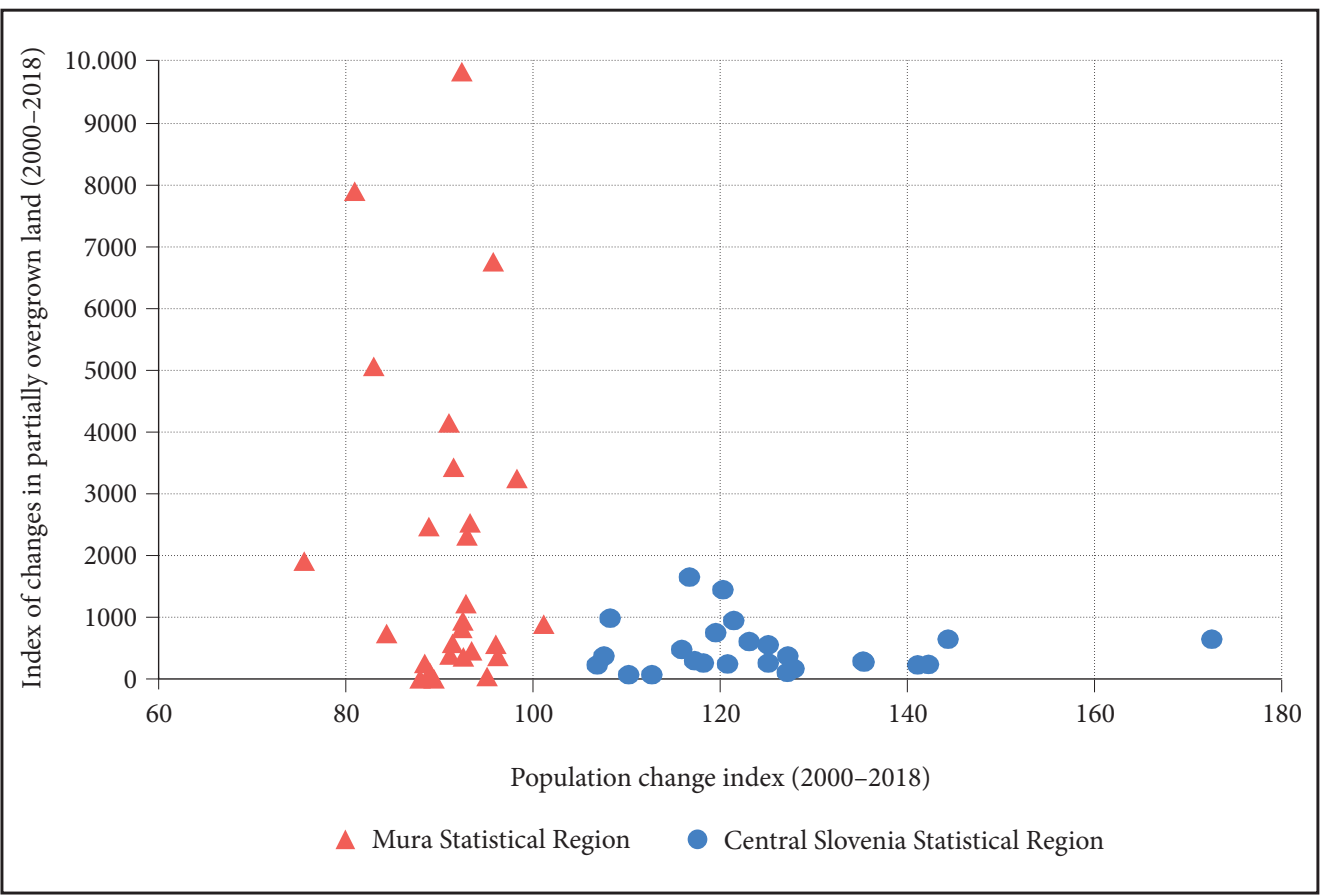

Figure 12: Population change index (2000-2018) and index of changes in partially overgrown land in municipalities of the Mura and Central Slovenia statistical regions.

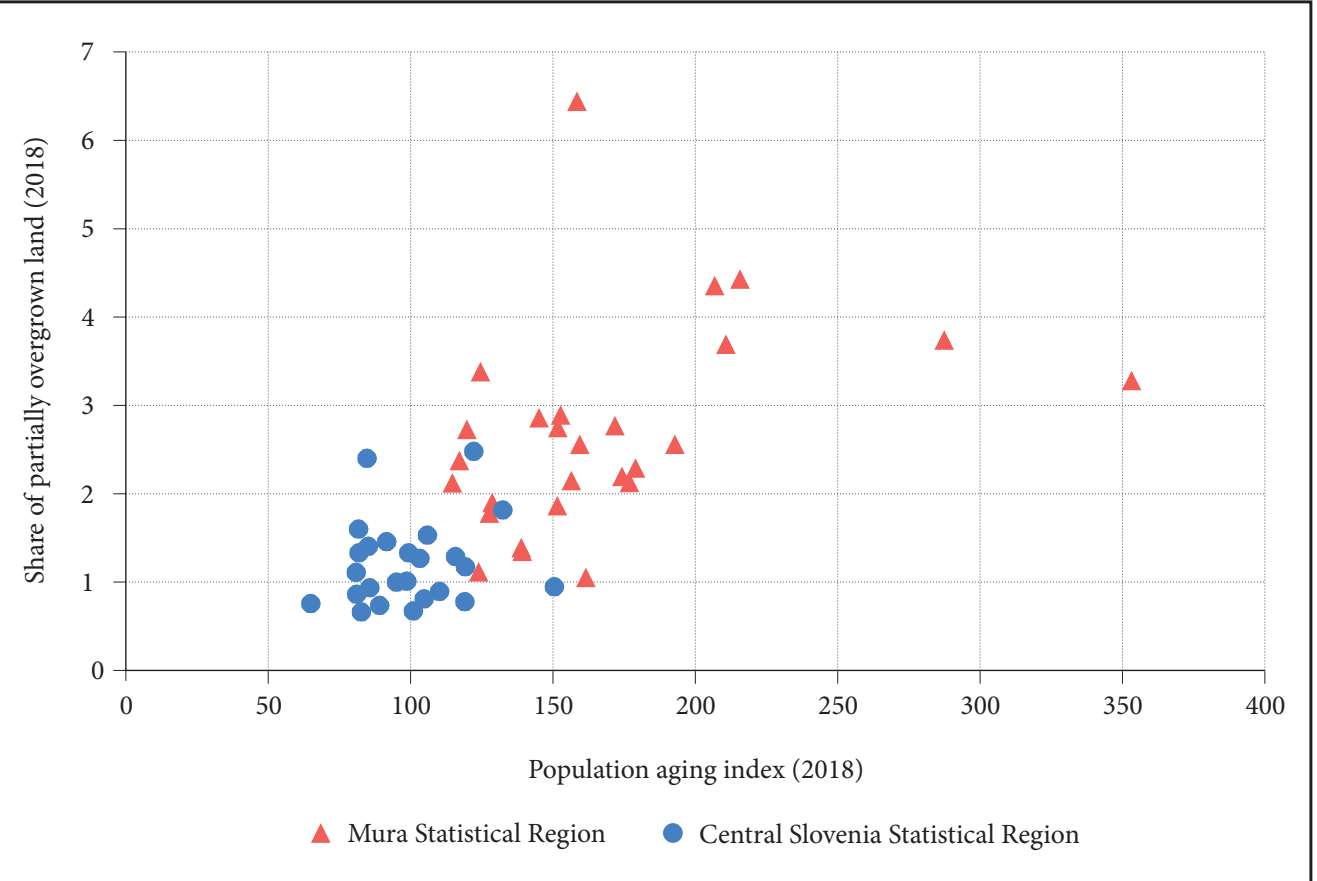

Figure 13: Population aging index (2018) and the share of partially overgrown land in municipalities of the Mura and Central Slovenia statistical regions. 


\begin{tabular}{|c|c|c|c|c|c|c|c|c|c|c|c|c|c|c|c|}
\hline $\begin{array}{r}(\angle L O Z) \\
\text { o!̣ex ұuәudo|әләр |ed!̣!unW }\end{array}$ & बढ. & & & $\begin{array}{l}\text { g. } \\
\text { i. } \\
1\end{array}$ & 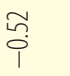 & $\begin{array}{c}\infty \\
\infty \\
0 \\
1\end{array}$ & \begin{tabular}{c|c}
$\infty$ \\
0 \\
1
\end{tabular} & $\widetilde{\sigma}$ & & & & & $\underset{0}{\stackrel{f}{0}}$ & & \\
\hline $\begin{array}{r}(\angle L O Z) \\
000^{\prime} \text { L Ləd uo!̣eub!u təN }\end{array}$ & & & & & $\stackrel{\text { nn }}{\circ}$ & & & & & & & & & & \\
\hline 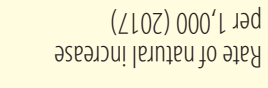 & ஐ & & & ஸे & $\begin{array}{l}\bar{\sigma} \\
0 \\
\end{array}$ & & & 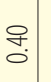 & & & & & & & \\
\hline 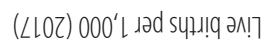 & & & & & & & & & & & & & & & \\
\hline 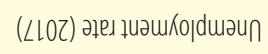 & & & & & $\stackrel{m}{\text { g. }}$ & & & & & & $\bar{n}$ & & & & \\
\hline 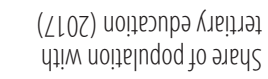 & $\stackrel{n}{0}$ & & & & ֻ̊ & 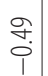 & \begin{tabular}{l}
$\widetilde{0}$ \\
\hdashline \\
$\circ$
\end{tabular} & $\underset{\sigma}{\sigma}$ & ஜి. & & & & & ஜூ & \\
\hline 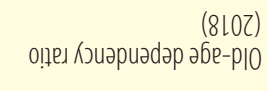 & 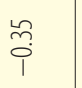 & & & & & $\stackrel{\vec{m}}{\tilde{\sigma}}$ & & $\begin{array}{c}\tilde{n} \\
\tilde{0} \\
1\end{array}$ & & & & & & & \\
\hline $\begin{array}{r}(810 Z) \\
+08 \text { uo!̣ejndod fo әruS }\end{array}$ & 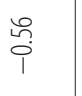 & $\tilde{\sigma}$ & & & \begin{tabular}{l}
$\infty$ \\
\multirow{2}{0}{}
\end{tabular} & 苞 & $\begin{array}{c}\text { f. } \\
0 \\
1\end{array}$ & $\begin{array}{l}\text { 会 } \\
0 \\
1\end{array}$ & & & & & & & \\
\hline 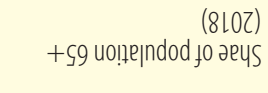 & $\begin{array}{l}\text { 우 } \\
\text { in } \\
1\end{array}$ & & & & fo & 年. & $\begin{array}{c}\stackrel{0}{0} \\
i \\
i\end{array}$ & $\begin{array}{c}\text { gे. } \\
0 \\
1\end{array}$ & & & & & & & \\
\hline $\begin{array}{r}\text { (8LOZ) } \\
\text { tL-0 uo!!ejndod jo ә«еuS }\end{array}$ & $\stackrel{\text { m. }}{0}$ & & & & 菅 & $\begin{array}{c}m \\
i \\
i\end{array}$ & $\stackrel{\overbrace{}}{\circ}$ & $\stackrel{m}{\sigma}$ & & & & & & & \\
\hline 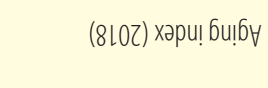 & $\stackrel{\text { fo }}{\stackrel{1}{~}}$ & & & & 융 & $\underset{0}{\stackrel{f}{0}}$ & $\begin{array}{c}\infty \\
\tilde{m} \\
i \\
1\end{array}$ & $\begin{array}{l}\text { J. } \\
0 \\
i\end{array}$ & & & & & & & \\
\hline $\begin{array}{r}(8107-000 z) \\
\text { әбиечว әбе әбеләлН }\end{array}$ & & & 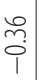 & & & $\begin{array}{l}\text { fi. } \\
0 \\
1\end{array}$ & F. & & & & & & & & \\
\hline (8เоz) әбе әбецәАн & f̊. & & & & g্ & F. & $\begin{array}{c}\infty \\
\cdots \\
i \\
1\end{array}$ & \begin{tabular}{c}
\multirow{2}{*}{} \\
0 \\
$i$
\end{tabular} & & & & & & & \\
\hline $\begin{array}{r}(810 z-000 z) \\
\text { хәри! әбиеч) uo!!̨|ndod }\end{array}$ & & & & & 年 & $\begin{array}{r}m \\
\vdots \\
i\end{array}$ & ळे. & & $\stackrel{\substack{f \\
0}}{2}$ & 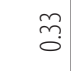 & & & & $\tilde{\varkappa}$ & 하 \\
\hline 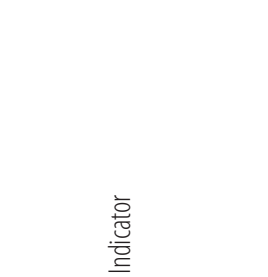 & 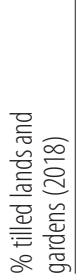 & 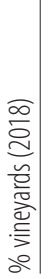 & 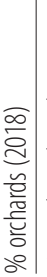 & 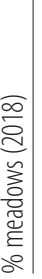 & 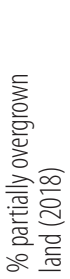 & 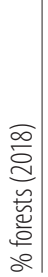 & 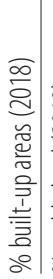 & 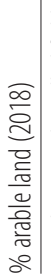 & 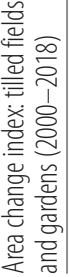 & 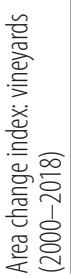 & 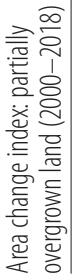 & 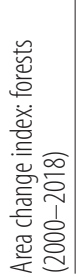 & 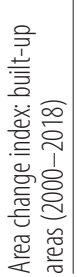 & 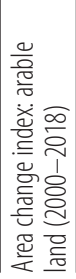 & 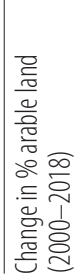 \\
\hline
\end{tabular}




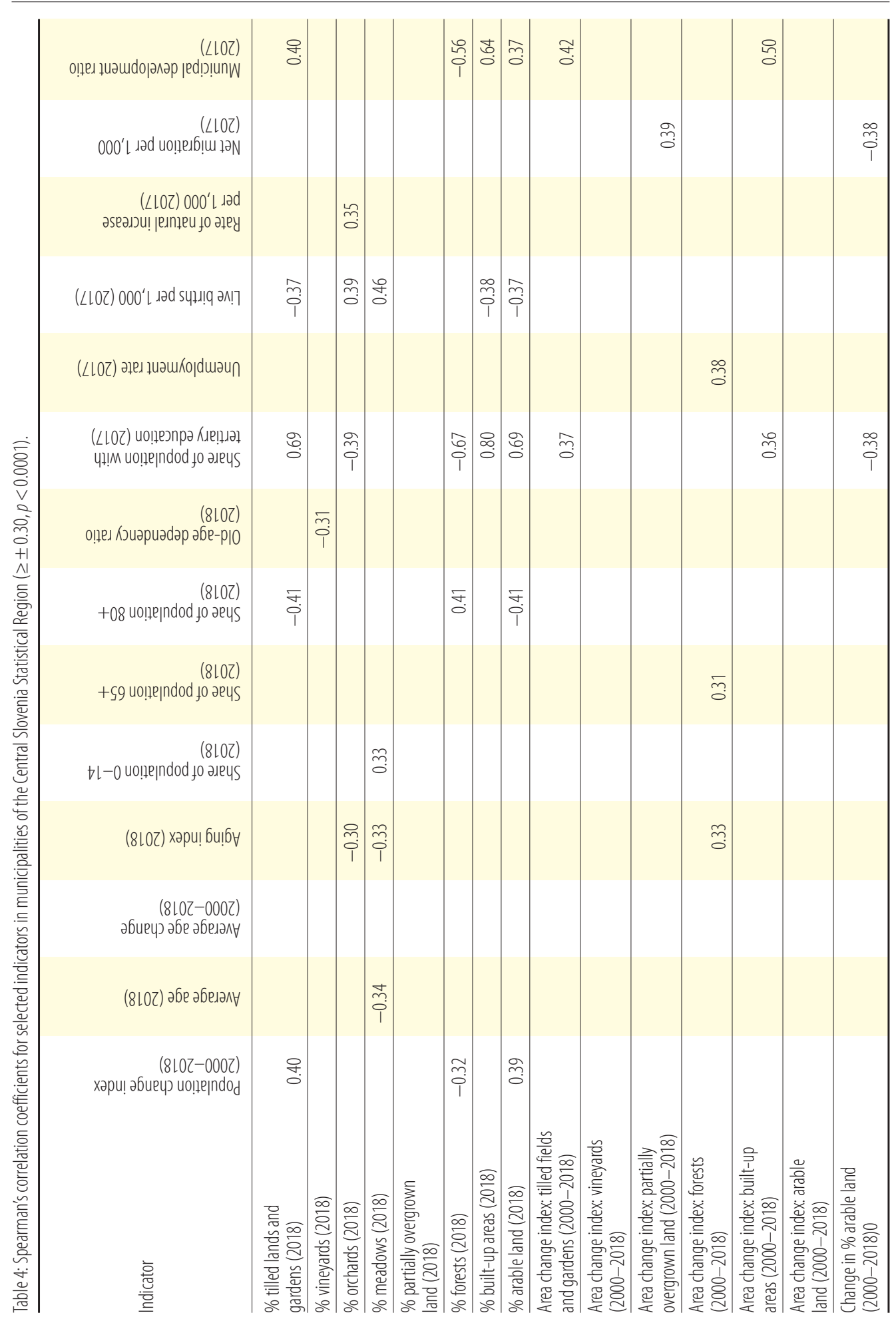


It is interesting that the population change and arable land change indices show a high correlation (0.53), being negative in most all the municipalities. As a rule, the scale of arable land in the Mura region is shrinking less in municipalities with a lower rate of depopulation. In the Central Slovenia region, the correlation coefficients between certain indicators are even higher (ranging from \pm 0.60 to 0.80 ). Standing out the most is the positive correlation between the share of population with tertiary education and indicators revealing a higher share of arable land, tilled fields, and gardens, whereas the population aging and depopulation indices are correlated with a higher share of forests and areas that are becoming increasingly overgrown with forest.

Attention should also be drawn to the fact that the correlation coefficients are higher with indicators showing the shares of individual land-use types, whereas correlations between land-use change processes and demographic indicators are relatively weak. Thus, only a positive correlation between demographic growth and an increase in the arable land can be highlighted in the Mura region and a positive correlation between an increase in forests and indicators revealing population aging and a higher unemployment rate in the Central Slovenia region.

\section{Conclusion}

Demographic changes in Europe, characterized by a decreasing and aging population, are a key factor influencing land-use changes. However, there is still insufficient evidence of the correlation between demographic changes and land-use changes, because quantitative studies dealing with such correlations are very rare and mostly cover small and specific areas. This study used land-use data and demographic and socioeconomic data at the level of Slovenian municipalities to calculate Spearman's correlation coefficients.

The coefficients for the whole of Slovenia are fairly low, confirming that land-use change processes are complex and not dependent solely on individual demographic and socioeconomic factors. Despite the low correlation coefficients, the results indicate that land-use change processes are significantly influenced by changes in the population's age structure and population growth. In areas where population is growing, the scale of arable land is decreasing, and in areas characterized by depopulation and an increasing aging index the scale of partially overgrown land is increasing. The highest positive correlation (0.48) was established between the share of population with tertiary education and an increase in the share of builtup areas, and the highest negative correlation $(-0.46)$ was determined between population growth and a decrease in arable land.

Because Slovenia has very heterogenous landscapes, the analysis then focused on a case study of the Mura and Central Slovenia statistical regions, which lie on opposite poles in terms of the municipal development ratio. In this case, correlation coefficients were significantly higher and sometimes even reached $\pm 0.50-0.60$; in terms of the municipal development ratio they even exceeded \pm 0.80 . The Mura region shows fairly clear positive correlations $(0.30-0.60)$ between indicators revealing population growth, a younger age structure, and a higher share of population with tertiary education, and indicators revealing a higher share of built-up areas. On the other hand, there are also positive correlations $(0.30-0.60)$ between indicators revealing population aging and depopulation, and indicators revealing a higher share of partially overgrown land and forest. In the Central Slovenia region, the correlation coefficients between certain indicators are even higher (ranging from \pm 0.60 to 0.80 ). Standing out the most is the positive correlation between the share of population with tertiary education and indicators revealing a higher share of arable land, tilled fields, and gardens, whereas the population aging and depopulation indices are correlated with a higher share of forests and areas that are becoming increasingly overgrown with forest.

Despite a weaker correlation than anticipated at the beginning of the study, the results show that demographic conditions should also be taken into account in addressing the abandonment of arable land, grass overgrowth, and afforestation. Similar future studies should also focus on other parts of Slovenia and expand the selection of relevant indicators. In this sense, it would be interesting to analyze the impact of migration on land-use change. 


\section{References}

Bičík, I., Gabrovec, M., Kupková, L. 2019: Long-term land-use changes: A comparison between Czechia and Slovenia. Acta geographica Slovenica 59-2. DOI: https://doi.org/10.3986/AGS.7005

Cuff, D. J., Goudie, A. S. 2009: The Oxford Companion to Global Change. Oxford.

Ferreira, A., Petek, F. 2005: Spremembe rabe in socialno-ekonomske sestave prebivalstva na zgornjem Gorenjskem. Zbornik gozdarstva in lesarstva 77.

Gabrovec M., Kladnik, D. 1997: Some New Aspects of Land Use in Slovenia. Geografski zbornik 37.

Gabrovec, M., Kumer, P. 2018: Land-use changes in Slovenia from the Franciscean Cadaster until today. Acta geographica Slovenica 59-1. DOI: https://doi.org/10.3986/AGS.4892

Gabrovec, M., Kumer, P., Ribeiro, D., Šmid Hribar, M. 2020: Land Use in Slovenia. The Geography of Slovenia. Cham.

Gallego, F. J., Palmieri A., Ramos H. 2015: Sampling system for LUCAS 2015. Bruxelles/Brussel. DOI: https://doi.org/10.2788/963

Gould, W. A., Martinuzzi, S., Parés-Ramos, I. K. 2012: Land use, population dynamics, and land-cover change in Eastern Puerto Rico. Water Quality and Landscape Processes of Four Watersheds in Eastern Puerto Rico. Reston.

Hansen, A. J., Rasker, R., Maxwell, B., Rotella, J., Johnson, J. D., Wright Parmenter, A., Langner, U., Cohen, W. B., Lawrence, R. L., Kraska, M. P. V. 2002: Ecological Causes and Consequences of Demographic Change in the New West: As natural amenities attract people and commerce to the rural west, the resulting land-use changes threaten biodiversity, even in protected areas, and challenge efforts to sustain local communities and ecosystems. BioScience 52-2. DOI: https://doi.org/10.1641/0006-3568(2002)052 [0151:ECACOD]2.0.CO;2

Horvat, U. 2006: Razvoj prebivalstva v mestu Maribor v obdobju med letoma 1981 in 2002. Revija za geografijo $1-1$.

Horvat, U. 2019: Prebivalstvo Maribora: razvoj in demografske značilnosti. Maribor.

Internet 1: https://ec.europa.eu/eurostat/web/lucas (15. 10. 2019).

Internet 2: http://rkg.gov.si/GERK/ (28. 10. 2018).

Internet 3: https://pxweb.stat.si/SiStat (5. 2. 2019).

Internet 4: http://www.pisrs.si/Pis.web/pregledPredpisa?id=URED7267 (26. 8. 2019).

Interpretacijski ključ, Podroben opis metodologije zajema dejanske rabe kmetijskih in gozdnih zemljišč. Ministrstvo za kmetijstvo, gozdarstvo in prehrano. Ljubljana, 2013. Internet:

http://rkg.gov.si/GERK/documents/RABA_IntKljuc_20131009.pdf

Kladnik, D. 1999: Leksikon geografije podeželja. Ljubljana.

Klemenčič, V. 1996: Tendence demografske preobrazbe v Spodnjem Podravju in vzhodnih Slovenskih goricah v zadnjih treh desetletjih. Spodnje Podravje s Prlekijo: možnosti regionalnega in prostorskega razvoja. Ljubljana.

Klemenčič, V. 2005: Poskus opredelitve sodobnih problemov razvoja kulturne pokrajine slovenskega podeželja. Dela 24.

Kroll, F., Haase, D. 2010: Does demographic change affect land use patterns?: A case study from Germany. Land Use Policy 27-3. DOI: https://doi.org/10.1016/j.landusepol.2009.10.001

Lisec, A., Pišek, J., Drobne, S. 2013: Suitability analysis of land use records of agricultural and forest land for detecting land use change on the case of the Pomurska Statistical Region. Acta geographica Slovenica 53-1.

Paušič, A., Čarni, A. 2012: Landscape transformation in the low karst plain of Bela krajina (SE Slovenia) over the last 220 years. Acta geographica Slovenica 52-1.

Pelc, S. 2015: Mestno prebivalstvo Slovenije. Koper.

Perpar, A., Kovačič, M. 2006: Prostorski vidiki razvoja kmetij. Dela 25.

Petek, F. 2002: Methodology of evaluation of changes in land use in Slovenia between 1896 and 1999. Acta geographica Slovenica 42.

Petek, F., Urbanc, M. 2004: The Franziscean Land Cadastre as a key to understanding the 19th-century cultural landscape in Slovenia. Acta geographica Slovenica 44-1. DOI: https://doi.org/10.3986/AGS44104

Plut, D. 2012: Prehranska varnost in Slovenija. Dela 38. 
Rajan, K. S, Shibasaki, S. 2000: A GIS Based Integrated Land Use/Cover Change Model to Study HumanLand Interactions. International Archives of Photogrammetry and Remote Sensing 33.

Ravbar, M. 1997: Slovenska mesta in obmestja v preobrazbi. Geografski zbornik 37.

Ravbar, M. 2007: Socialno-geografska preobrazba naselbinskih struktur - kako usmerjati razvoj? Dela 27. DOI: https://doi.org/10.4312/dela.27.81-100

Rebernik, D. 1999: Prebivalstveni razvoj Ljubljane po letu 1945. Geografski vestnik 71.

Rebernik, D. 2008: Urbana geografija - Geografske značilnosti mest in urbanizacije v svetu. Ljubljana.

Ribeiro, D. 2017: Impact of landscape features on land use and regional development in karst areas: a case study of Bela krajina. Ph. D. thesis, University of Ljubljana. Ljubljana.

Ribeiro, D., Ellis Burnet, J., Torkar, G. 2013: Four windows on Borderlands: Dimensions of place defined by land cover change data from historical maps. Acta geographica Slovenica 53-2. DOI: https://doi.org/ 10.3986/AGS53204

Ribeiro, D., Šmid Hribar, M. 2019: Assessment of land-use changes and their impacts on ecosystem services in two Slovenian rural landscapes. Acta geographica Slovenica 59-2. DOI: https://doi.org/10.3986/ AGS.6636

Shi, Y., Wang, R., Fana, L., Li, J., Yang, D. 2010: Analysis on Land-use Change and Its Demographic Factors in the Original-stream Watershed of Tarim River Based on GIS and Statistic. Procedia Environmental Sciences 2. DOI: https://doi.org/10.1016/j.proenv.2010.10.021

Tiran, J. 2017: Kakovost bivalnega okolja v Ljubljani. Ljubljana.

Vrabič Kek, B. 2012: Kakovost življenja. Ljubljana.

Žiberna, I. 2013: Spreminjanje rabe tal v Sloveniji v obdobju 2000-2012 in prehranska varnost. Revija za geografijo 8-1.

Žiberna, I. 2018: Spremembe rabe na območjih, ki so strateškega pomena za kmetijstvo in pridelavo hrane v obdobju 2000-2017. Revija za geografijo 13-1. 